\title{
"Gênero é pedofilia, zoofilia e necrofilia": a destruição da família e as ideologias de gênero e gênesis nos discursos de Magno Malta
}

\author{
Eduardo Meinberg de Albuquerque Maranhão Fo.*
}

\section{Resumo}

A partir de discursos do político evangélico Magno Malta e de notícias veiculadas na mídia sobre o mesmo, apresento neste texto alguns dos modos como uma certa "ideologia de gênesis" (MARANHÃO Fº, 2018a e b) tem se consolidado na contemporaneidade recente como perpetradora de um dispositivo da cis-heteronorma, da sofismática "ideologia de gênero", da bélica resistência aos estudos que objetivam a justiça e igualdade de gênero e da sinalização de possível rompimento da laicidade do Estado.

Palavras-chave: Ideologia de gênero; gênero e religião; dispositivo da sexualidade.

\section{"Gender is pedophilia, zoophilia and necrophilia":}

The destruction of the family and the ideologies of gender and genesis in the speeches of Magno Malta

Abstract: From the speeches of the evangelical politician Magno Malta and the media reports on the same, I present in this text some of the ways in which a certain "ideology of genesis" has consolidated in recent times as the perpetrator of a cis-heteronorma device , the sophistical "gender ideology", the warlike resistance to studies that aim at justice and gender equality, and the signaling of a possible dissolution of the laity of the state. Key-words: Gender ideology; gender and religion; device of sexuality.

\footnotetext{
Presidência da AMAR (Associação Internacional de Estudos de Afetos e Religiões. PósDoutorados em Ciências das Religiões pela Universidade Federal da Paraíba (UFPB), em História pela Universidade Federal de Santa Catarina (UFSC), e Interdisciplinar em Ciências Humanas também pela UFSC. Doutorado em História Social pela Universidade de São Paulo (USP). Mestrado em História do Tempo Presente pela Universidade do Estado de Santa Catarina (UDESC). Coordenação Científica da Fogo Editorial. Contato: edumeinberg@gmail.com.
} 


\section{"Género es pedofilia, zoofilia y necrofilia":La destrucción de la familia y las ideologías de género y de génesis en los discursos de Magno Malta}

\section{Resumen}

A partir de discursos del político evangélico Magno Malta y de noticias transmitidas en los medios sobre el mismo, presento en este texto algunos de los modos como una cierta "ideología de génesis" se ha consolidado en la contemporaneidad reciente como perpetradora de un dispositivo de la cis-heteronorma, de la sofismática "ideología de género", de la bélica resistencia a los estudios que objetivan la justicia e igualdad de género y de la señalización de una posible disolución de la laicidad del Estado.

Palabras clave: Ideología de género; género y religión; secularismo; dispositivo de la sexualidad.

"Nós, representantes do povo brasileiro, reunidos em Assembléia Nacional Constituinte para instituir um Estado Democrático, destinado a assegurar o exercício dos direitos sociais e individuais, a liberdade, a segurança, o bemestar, o desenvolvimento, a igualdade e a justiça como valores supremos de uma sociedade fraterna, pluralista e sem preconceitos, fundada na harmonia social e comprometida, na ordem interna e internacional, com a solução pacífica das controvérsias, promulgamos, sob a proteção de Deus, a seguinte CONSTITUIÇÃO DA REPÚBLICA FEDERATIVA DO BRASIL. Art. 19. É vedado à União, aos Estados, ao Distrito Federal e aos Municípios: I - estabelecer cultos religiosos ou igrejas, subvencioná-los, embaraçarlhes o funcionamento ou manter com eles ou seus representantes relações de dependência ou aliança, ressalvada, na forma da lei, a colaboração de interesse público". (CONSTITUIÇÃO DA REPÚBLICA FEDERATIVA DO BRASIL,1988).

\section{"Nós}

começamos esta jornada orando. E o mover de Deus - e ninguém vai explicar isso nunca, o que acontece - os tentáculos da esquerda jamais seriam arrancados sem a mão de Deus, chegamos, começamos orando e nada mais que justo que agora oremos para agradecer a Deus. Então vamos dar as nossas mãos todos e vamos orar neste momento. Senhor meu Deus e meu Pai, neste momento nós te somos agradecidos, foi um ano de luta falando com o povo, pedindo a tua proteção, falando sobre família, falando sobre o nosso país, cuidado das nossas crianças, Deus na vida, Deus na vida da família, na vida do Brasil, lutando contra a corrupção, enfrentando tudo e todos (...) Agradecemos o Senhor pelo que fez, levantou Jair Bolsonaro, duas vezes, porque o Senhor não permitiu que a morte o tragasse no momento de expectativa e de sonho do povo brasileiro (...) Ele está de pé. Oh, Deus, 
a vitória concretizada. Agora dê a ele sabedoria, compreensão ao povo brasileiro e a todos nós, para que ele possa ter tempo, Senhor, pra poder reparar, desfazer minas que foram colocadas, e devolver dias felizes de alegria ao povo brasileiro, às nossas crianças, às nossas escolas, e às nossas famílias. A tua Palavra diz que quem unge a autoridade é Deus, e o Senhor ungiu Jair Bolsando, e a partir desta data, Senhor, ele passa a ser o presidente de todos nós, um presidente que ama a Pátria, um cristão verdadeiro, um patriota, cheio de fé, de coragem e de esperança. Agradecemos por isso (...) desde aquela senhora que orava de madrugada, a outra que rezava, evangélicos, espíritas, católicos, confissões de fé de um país majoritariamente cristão. Obrigado Jesus pela família dele (...) obrigado por esta hora de festa no Brasil e no mundo, agradecemos em nome de Jesus, o Brasil acima de tudo e Deus acima de todos". (MALTA, 28/10/2018).

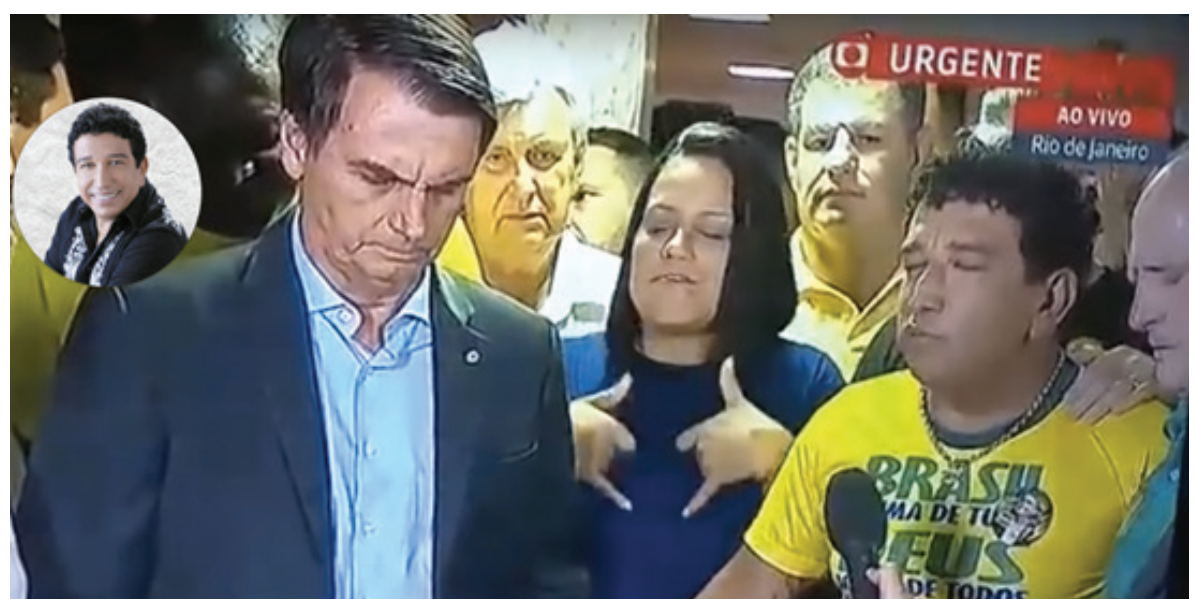

Imagem: Oração de Magno Malta na Vitória de Jair Bolsonaro

Fonte: Canal de Youtube de Magno Malta: https://www.youtube.com/ watch?v $=$ ixUfHHJnMjo

O segundo trecho da página anterior se refere à oração feita pelo então senador e pastor Magno Malta, do Partido da República / PR-ES (à direita, trajando camiseta verde e amarela com os dizeres Brasil acima de tudo, Deus acima de todos) a Jair Messias Bolsonaro (Partido Social Liberal / PSLRJ), recém eleito presidente do Brasil em 28 de outubro de 2018. ${ }^{1}$ Podemos

Tal slogan pode ser compreendido também como "fake news acima de tudo, fake news acima de todos", visto que, "dentre outros elementos possíveis, Bolsonaro foi eleito presidente por conta da veiculação de notícias inverídicas em redes sociais como o WhatsApp, Twitter e Facebook sobre temas como "kit gay" e "ideologia de gênero", objetivando causar um sentimento de terror social pelo suposto extermínio da "família tradicional brasileira" (MARANHÃO Fo, COELHO, DIAS, 2018). 
indagar preliminarmente: Mesmo estando dentro de sua residência no Rio de Janeiro no momento do pronunciamento, será que conviria a um chefe de Estado recém eleito "puxar reza" sob os olhares de grande parte do país e a minutos de seu primeiro discurso público após eleito? Será que as pessoas que participaram da Assembleia Constituinte que promulgou nossa Constituição Federativa em 1988 poderiam imaginar que em 2018 - 30 anos depois - o primeiro pronunciamento público de um presidente recém eleito seria precedido por uma oração típica de cultos evangélicos?

Importa notar no preâmbulo da Constituição da República Federativa do Brasil que a mesma foi promulgada "sob a proteção de Deus", ou seja, que há o reconhecimento por parte do Estado da existência de Deus, ainda que isso não tenha força normativa. Tal reconhecimento demonstra que o Estado não é ateu e nem a-religioso, o que não significa que o mesmo tenha uma religião oficial ou que possa privilegiar religiões específicas. A laicidade, princípio constitucional no ordenamento jurídico brasileiro e questão de Direitos Humanos, reveste o Estado de neutralidade religiosa afim de assegurar a liberdade de crença, de culto e de organização religiosa e garantir que não haja privilégios a determinada(s) religião(ões) ou crença(s) e prejuízo a outras, bem como ao ateísmo, agnosticismo e formas de descrença. A laicidade do Estado é patente ao permitir e garantir a liberdade do indivíduo em professar qualquer religião, crença ou descrença; e é ela que assevera, ainda, a separação entre Igreja e Estado, ou ainda entre qualquer religião e Estado ou mesmo religião e política: o Estado não deve, de modo geral, interferir em questões religiosas, e a religião não deve interferir em questões estatais. Decisões administrativas, jurídicas e políticas não devem ser orientadas ou comungar com qualquer religião, ainda que haja a possibilidade constitucional de colaboração recíproca entre Estado e religiões em ações de interesse comum (como a Pastoral da Criança gerida pela Igreja Católica, por exemplo).

A oração de Magno Malta ao recém eleito presidente Jair Bolsonaro pode dar vistas à flexibilização e/ou rompimento da laicidade do Estado, como se percebe. Alguns dos primeiros pronunciamentos do Presidente recém eleito, aliás, sinalizam o rompimento do princípio da laicidade do Estado. Bolsonaro iniciou seu pronunciamento com a passagem bíblica de João 8:32 ("conhecereis a verdade e a verdade vos libertará") e apresentou-se como missionário de Deus. Minutos antes, em cerimônia pública, convidou Malta a pronunciarse. Além de ungir Bolsonaro, este contemplou que o mesmo foi posto no mando da nação por Deus. O slogan da campanha presidencial, no mesmo 
sentido, já causava preocupação: "Deus acima de todos". Em uma sociedade verdadeiramente inclusiva, democrática, plural e laica, o respeito à diversidade de crenças (e também de descrenças, ao ateísmo e ao agnosticismo) deve ser devidamente assegurado. É urgente que a laicidade do Estado, prevista pela nossa Constituição Federal, seja devidamente assegurada.

A indesejável "flexibilização" da laicidade do Estado pode ser identificada em pronunciamentos de Magno Malta no Senado Federal quando ele diz que o Brasil não só é um país majoritariamente cristão como é absolutamente cristão (BRASIL, 2015, s/p), o que "justificaria" a contaminação do religioso no político, tendo como (d)efeito o soterramento das demais manifestações de religiosidade, espiritualidade, crença e descrença.

Além disso, Malta representou o Brasil como Senador em diversas missões no exterior, como a de "proferir palestras a convite da Primeira Igreja Batista de Língua Portuguesa, em Nova York, EEUUA" em julho de 2004 e ministrar "palestras para a comunidade brasileira em Nova York a convite da First Portuguese Speaking Baptist Church of New York - EUA" em setembro de 2008 (BRASIL, s/d), o que sinaliza para uma relativização / ruptura da laicidade do Estado, responsável pela separação entre Estado e Igreja e garantia de que recursos públicos não sejam utilizados para fins religiosos / devocionais / confessionais / proselitistas. O senador costuma demonstrar o que pensa sobre laicidade do Estado: "Alguns dizem, de forma hipócrita - alguns Senadores, alguns Deputados Federais, alguns políticos e alguns jornalistas esquerdopatas: "É preciso separar religião de política." Separar o que de quê?", e prossegue: "É possível separar um homem das suas convicções? Claro que não! (...) Alguém pode separar Magno Malta da sua fé? Não!" (BRASIL, 2017).

Antes de prosseguirmos com este diálogo, cabe perguntar: Afinal, quem é Magno Malta, o pastor que ungiu e abençoou Jair Messias Bolsonaro, e a partir de que conceito ele costuma articular o que entende ser a defesa da família, das escolas e das crianças, anunciada na sua oração?

O inferno está soprando contra as famílias valores que conduzem à iniquidade, Ergo a minha voz, ordeno com autoridade: "Projetos do inferno contra as famílias, caiam em nome de Jesus"

Michelle Nascimento 
Mas, pra mim, só vale o que está escrito A Bíblia, que pro homem só há um caminho Tempero do Mundo Magno Malta

Baiano de Macarani, Magno Pereira Malta nasceu em 16 de outubro de 1957. Casado com a deputada federal e cantora Lauriete Rodrigues de Almeida e pai de três filhas, é pastor evangélico, formado em Teologia pelo Seminário Teológico Batista do Norte do Brasil (Recife-PE) e cantor do conjunto de pagode gospel Tempero do Mundo (este da epígrafe acima), fundado em 1994 e integrado por suas filhas Madga e Carla, além de outros músicos.

Iniciou sua carreira política em 1993 como vereador de Cachoeiro de Itapemirim, Espírito Santo. Em uma ascensão considerada meteórica por algumas pessoas, se elegeu deputado estadual no ano seguinte pelo Partido Trabalhista Brasileiro (PTB) com 10.997 votos. Em 1998 foi eleito deputado federal pelo mesmo partido com 54.754 votos. Destacou-se, dentre outras coisas, pela presidência da Comissão Parlamentar de Inquérito (CPI) do Narcotráfico. Através do Partido Liberal (PL) Malta foi eleito senador com 867.434 votos em 2002. Dentre outras atividades, presidiu a CPI da Pedofilia. Malta foi reeleito senador pelo Espírito Santo em 2010 com 1.285.177 votos. Nas eleições de 2018 não conseguiu se reeleger como senador pelo seu estado, ficando em terceiro lugar na disputa. Participou de diversas comissões no Senado, como a Comissão de Constituição, Justiça e Cidadania (CCJ), a Comissão de Direitos Humanos e Legislação Participativa (CDH), a Comissão Parlamentar de Inquérito dos Maus-Tratos (CPIMT) e a Comissão de Educação, Cultura e Esporte (CE). Além do PTB e PL, Malta também foi filiado ao Partido do Movimento Democrático Brasileiro (PMDB), Partido Social Trabalhista (PST) e atualmente ao Partido da República (PR). Se notabilizou por se posicionar favoravelmente pelo fim da maioridade penal, contra mudanças no sistema de distribuição dos royalties do petróleo que afetassem negativamente o Espírito Santo como produtor. Além disso, ficou conhecido por ter votado a favor da PEC do teto dos Gastos Públicos (dezembro de 2016), do impeachment da ex-presidenta Dilma Rousseff (2016) e da Reforma Trabalhista (julho de 2017).

Em 2016 o perfil de Malta na Wikipedia foi adulterado através de um computador utilizado no Senado Federal e as informações acerca de controvérsias e escândalos o envolvendo, apagadas. Atualmente, o conteúdo 
encontra-se novamente disponível no site. Dentre os escândalos encontra-se uma miríade de suspeitas de corrupção. Em uma delas, Malta foi indiciado pela CPI dos Sanguessugas ao ter seu nome envolvido em 2007 na denúncia de desvio de recursos públicos destinados à compra de ambulâncias do Ministério da Saúde. Foi absolvido pela Comissão de Ética do Senado, orientada pelo parecer do relator Demóstenes Torres sugerindo arquivamento por falta de provas. Em outra suspeita, seu nome constou do escândalo dos Atos Secretos em 2009, envolvendo denúncias relativas à não publicação de atos administrativos, bem como medidas impopulares e nepotismo (como a extensão de assistência psicológica e médica vitalícia a cônjuges de exparlamentares). Outra das suspeitas de corrupção se deu em 2016, quando foram publicados pela Folha de S. Paulo trechos de emails enviados em 2014 e que indicariam uso de nota fria e pretenso repasse a Malta no valor de R\$ 100 mil não-declarados por consultoria à Itatiaia, fabricante de móveis. À época Malta associou as acusações à exposição de sua imagem pública durante o processo de impeachment da presidenta Dilma Rousseff.

Malta também é famigerado por controvérsias diversificadas. Entre estas, foi acusado de gastar quase meio milhão de reais ( $\mathrm{R} \$ 472$ mil) de cota parlamentar em combustível em dois postos de gasolina de Vila Velha, Espírito Santo, entre abril de 2009 e julho de 2018. Outra acusação foi a de ter recebido propinas em troca de obras superfaturadas, juntamente com seu partido (o PR), que lidera o Ministério dos Transportes e é responsável pela contratação de empreiteiras para realizar obras de investimentos vultosos. Seu processo de reeleição em 2010 também sofreu denúncias de irregularidades. Em uma delas, possivelmente envolvendo o Ministério dos Transportes comandado pelo PR, a campanha de Malta teria recebido de construtoras e empreiteiras $\mathrm{R} \$ 1.700 .000$ dos quase 3 milhões arrecadados (60\% do total) em doações. Posteriormente, diversas empresas que financiaram a campanha ganharam licitações questionadas pelo Tribunal de Contas da União, como a SA Paulista, a Serveng e a Contractor.

Sua reeleição ocorreu em boa parte por conta de sua campanha enfatizando as CPIs do Narcotráfico e da Pedofilia. Contudo, a campanha foi criticada pela Associação de Pastores Evangélicos da Grande Vitória, pelo Fórum Político Evangélico do Espírito Santo e por outros setores evangélicos, bem como pelos bispos da Província Eclesiástica do Espírito Santo, que protestaram através de carta pela exposição de crianças e adolescentes: "orientamos todos os católicos que se posicionem criticamente diante desta campanha que coloca o foco na CPI da pedofilia e na CPI do narcotráfico 
(...) não concordamos que a dor, a humilhação e o sofrimento das crianças e adolescentes vítimas de abuso sexual e tráfico de drogas e de armas, sejam transformados em espetáculo para angariar votos." Outra acusação sobre Malta é a de denúncia falsa e incitação e participação em tortura. Luiz Alves de Lima, ex-cobrador de ônibus, narrou que Malta o acusou de ter estuprado sua própria filha de dois anos e, após preso, ter incitado e participado de sua tortura, que dentre outras coisas fez com que ficasse cego de um olho e com 25\% de visão no outro. Após a Justiça ter absolvido Lima em 2016 por provas de que não havia ocorrido violência contra a menor, o mesmo buscou indenização do Estado, recebendo uma pensão mensal de R \$ 2 mil.

Outras controvérsias envolvendo Malta dizem respeito a questões de gênero e sexualidade. Malta é relator da Sugestão Legislativa nº15/2014, enviada por um cidadão paulista ao Portal e-Cidadania e que pretende regular a interrupção voluntária da gravidez nas 12 primeiras semanas de gestação pelo Sistema Único de Saúde (SUS). Apesar de 51\% da população ter sido favorável à proposta, Malta optou pela rejeição em seu relatório. Outra polêmica esteve no posicionamento de Malta sobre o Projeto de Lei 122/2006, e autoria da deputada Iara Bernardi, e que pretendia criminalizar a homofobia. Para Malta, que relacionou o PL à pedofilia, zoofilia, bestialidade, sadomasoquismo e necrofilia (BRASIL, 2008, s/p), ${ }^{2}$ este "censuraria" padres e pastores que proibissem fiéis de se beijarem dentro das igrejas e em outros lugares públicos. ${ }^{3}$ Mas certamente, o assunto mais controverso de Malta tem sido relativo ao combate à (suposta) ideologia de gênero - contenda que tem servido como conceito articulador do que o senador ${ }^{4}$ entende ser a defesa da família e das crianças em contexto escolar.

\section{A ideologia de gênero de Magno Malta}

Provavelmente o mais proeminente paladino dos combates às hordas malévolas que preparam Projetos de Lei infernais (como o "kit gay" e o PL contra a homofobia) no Senado Federal tenha sido Malta. No sítio do Senado há a transcrição - entre 2011 e 2017 - de pelo menos 15 pronunciamentos próprios

2 Malta utilizou a vinculação entre projetos que visam salvaguardar a segurança física, moral e jurídica de pessoas homossexuais/afetivas e transgêneras com parafilias (pedofilia, necrofilia, bestialidade, zoofilia) em diversas vezes (BRASIL, 2007; 2009; 2017 dentre outras - os links para acesso encontra-se ao final do texto).

As referências advindas da mídia encontram-se ao final do artigo.

4 Refiro-me a Malta como senador pois na época da confecção do texto $(12 / 2018)$ ele ainda cumpria seu segundo mandato, previsto até dezembro de 2018. 
(além de apartes em manifestações de colegas) "revelando" a "ideologia de gênero" como mal a ser impugnado e aludindo aos versos que identificam a geração de Adão e Eva. Presidindo a Frente Parlamentar da Família (FPF), Malta razoa em 24/05/2011 que o chamado "kit gay" "fará das escolas do Brasil verdadeiras academias de homossexuais" e que "uma minoria barulhenta tenta se sobrepor" às famílias que creem que "Deus assim a constituiu, macho e fêmea, homem e mulher, pai e mãe - aliás, viemos do útero de uma mulher, não há qualquer anomalia que possa trazer alguém à luz fora disso" (BRASIL, 2011, $\mathrm{s} / \mathrm{p}$ ). Dois dias depois Malta alcunha o PL 122 (que criminaliza a homofobia) de "nefasta aberração", apelando para a concepção de família natural e biológica: "Ninguém nunca foi gerado fora do útero. Deus criou macho e fêmea. Ninguém foi gerado fora do útero. Ninguém! Não há a menor possibilidade do ser humano não ser gerado por macho e fêmea". Além disso, com a Lei, as pessoas não poderiam mais rejeitar a visita de um casal homossexual em suas casas e estariam à mercê de uma cota para homens homossexuais na sociedade (BRASIL, 2011, s/p). Em 20/11/2013 novamente demonstra repúdio ao PL 122 e absurdo que uma pessoa seja impedida de alugar uma casa a um homossexual ou demiti-lo por conta de sua orientação sexual. Infere que "se Deus não tomar uma providência com este País, vai ter que se desculpar com Sodoma e Gomorra" (aludindo à suposta homossexualidade existente nos versos bíblicos sobre tais cidades) pois "a família tradicional foi instituída por Deus - macho e fêmea, homem e mulher" e "ninguém fica grávida de um homossexualzinho porque não há cromossomo homossexual" (BRASIL, 2013, s/p). Os demais pronunciamentos de Malta entre 2011 e 2017 no Senado relacionam no mesmo discurso pedofilia e ideologia de gênero, reforçam as ideias de que haveria uma "ditadura gay" que impediria as pessoas heterossexuais/afetivas de rejeitarem a convivência com as homossexuais, e pregam que a família só poderia ser constituída biológica e naturalmente por homem e mulher héteros, como Deus criou. ${ }^{5}$

Em 2018 Malta se referiu ao assunto em pelo menos três vezes no Senado. Em 05 de fevereiro de 2018, por exemplo, Malta fez um pronunciamento no Senado dizendo que 2018 seria um ano de muita luta, marcado pelo combate à "tentativa absurda de mudar uma ordem social com a chamada ideologia de gênero" e que "a ideologia de gênero é uma tentativa de mudar a nova ordem social. O absurdo dos absurdos. Será um ano de

Todos estes pronunciamentos encontram-se no sítio do Senado Federal: www25. senado.leg.br. 
enfrentamento mais uma vez. E faremos, porque é o enfrentamento de uma maioria contra uma minoria, que grita muito, mas é minoria." Na sequência, associou a mesma a supostos discursos comunistas que estimulariam incesto, zoofilia e destruição patrimonial e da família tradicional: "Faça o incesto, ensine o sexo com um animal, destrua a família tradicional. Assim, nós destruiremos o patrimônio, faremos a anarquia na sociedade.” (BRASIL, 2018, s/p).

Malta também relacionou comunismo, aniquilamento da família, ideologia de gênero, pedofilia e zoofilia em diversos discursos, como este:

Esse ataque sistemático é o texto próprio do Karl Marx, na sua tese, quando começou a discutir o comunismo para o mundo: "Destrua a família. Destrua os seus valores. Exponham as crianças. Erotize as crianças. Mostre às crianças a bestialidade, o sexo com animal." Trata-se da zoofilia, mas o termo mais correto é bestialidade. "Mostre a elas. Homens... Dois, três homens, abusando de uma só criança. Conjunção carnal. Desmoralização. Faça isso. Exponha o nu. E aí, sim, destruiremos esses valores.” Disse ele que o grande problema da sociedade é a família, porque elas detêm o patrimônio (BRASIL, 2017, s/p).

A partir de uma concepção desinformada e deformada do marxismo, Malta aciona o temor relativo à hecatombe dos valores familiares: segundo ele, estudar gênero relacionaria-se com o comunismo/marxismo que por sua vez estimularia sexo grupal, homossexualidade, erotização precoce, pedofilia e zoofilia (ou bestialidade). À reboque destas correlações, Malta já relacionou sexo com crianças (pedofilia), sexo com animais (zoofilia) e sexo com cadáveres (necrofilia) com a laicidade do Estado e com livros didáticos que estimulam debates sobre gênero e sexualidade: "quando aprovarmos a pedofilia como coisa normal, não como crime, está aprovada a bestialidade, a necrofilia (BRASIL, 2013, s/p)". Reportagem do Senado Notícias mostrou que Malta

denunciou a proliferação de livros didáticos que, em sua avaliação, destroem os valores da família, e criticou o uso do argumento da separação entre Igreja e Estado como pretexto para diminuir o espaço da formação religiosa dos estudantes (BRASIL, 2013, s/p).

Em seus discursos, Malta demonstra a concepção de que não deve haver separação entre Igreja e Estado e que este deve prover educação religiosa cristã às pessoas cidadãs. Além disso, ao citar livros didáticos Malta alude a materiais de combate à discriminação de gênero propostos pelo governo à época de seu discurso e falaciosamente interpretados como "kit 
gay" - uma fake new bastante propagada e que em conjunto com o sofisma da "ideologia de gênero" auxiliou a impulsionar a campanha e a assunção de Jair Bolsonaro à presidência. ${ }^{6}$ Estas declarações de Malta - um dos patriarcas das fake news acerca de gênero no país - se enfeixam em um dispositivo da cis-heteronorma que por sua vez comunga diretamente com uma certa ideologia de gênesis (MARANHÃO $\mathrm{F}^{\circ}, 2018 a$ e b) ${ }^{7}$ - ambas visando o confronto com a suposta ideologia de gênero.

\section{O dispositivo da cis-heteronorma e sua ajudadora, a ideologia de gênesis}

De acordo com Michel Foucault dispositivo é

um conjunto decididamente heterogêneo que engloba discursos, instituições, organizações arquitetônicas, decisões regulamentares, leis, medidas administrativas, enunciados científicos, proposições filosóficas, morais, filantrópicas. Em suma, o dito e o não dito são os elementos do dispositivo, o dispositivo é a rede que se pode estabelecer entre esses elementos (FOUCAULT, 2000, p. 244).

Este dispositivo seria "uma espécie de novelo ou meada, um conjunto multilinear” (DELEUZE, 1990, p. 155) e consistiria na maquinaria responsável por normalizar e normatizar / descrever e prescrever relações pessoais, culturais e sócio-políticas as estruturando de maneira hierarquizada. O dispositivo é o arcabouço de saberes e poderes que provê e reforça privilégios mantendo a potestade de um coletivo (exemplarmente: homens brancos, universitários, de classe econômica alta, nascidos no sudeste/sul brasileiro, cisgêneros, hétero, cristãos e sem deficiência) em relação a outros (por exemplo: mulheres, pessoas indígenas, negras, nortistas, nordestinas, de baixa renda, transgêneras, não-hétero, não-cristãs e com deficiência). É possível não só entendermos todos estes marcadores sociais (dentre outros) como componentes de um dispositivo ampliado de manutenção de proveitos de um coletivo sobre outro, como também observarmos dispositivos específicos

6 Como observa o Senado Notícias em relação ao kit gay, "o TSE o classificou como notícia falsa, o que não impediu que a campanha de Jair Bolsonaro explorasse o tema em seu último programa eleitoral na TV. Ainda assim, nenhuma providência foi tomada pelo Tribunal após a divulgação do programa." (BRASIL, 2018). Sobre o kit gay, a ideologia de gênero e o fim da "família tradicional brasileira" como fake news que estimularam a eleição de Bolsonaro, acessar: MARANHÃO Fo, COELHO, DIAS, 2018.

Acerca da ideologia de gênesis, também recomendo: (MARANHÃO Fº FRANCO, 2019). 
em relação a dados marcadores. Foucault faz notar um destes dispositivos, o da sexualidade, que "tem, como razão de ser, não reproduzir, mas o proliferar, inovar, anexar, inventar, penetrar nos corpos de maneira cada vez mais detalhada e controlar as populações de modo cada vez mais global" (FOUCAULT, 1988, p. 100). Nesta mesma esteira, Letícia Lanz contempla um dispositivo binário de gênero "que determina o enquadramento das pessoas em um dos dois gêneros oficialmente reconhecidos - homem e mulher, ou masculino e feminino, em função do órgão sexual que elas trazem entre as pernas ao nascer" (LANZ, 2014, p. 25).

Pode-se ainda cogitar um dispositivo da cisgeneridade ou da cisnorma:

a rede de relações entre saberes, dizeres e poderes que direcionam as concepções mais generalizadas na sociedade a respeito de gênero, enraizadas na percepção de que há uma normatividade a ser seguida, associada ao sexo/ gênero binário, e dentro dos parâmetros da cisgeneridade. Esse conjunto de concepções e poderes dá substância ao preconceito, discriminação e intolerância a pessoas que não se adequam ao que se espera de uma pessoa cisgênera, ou seja, que atuem no mundo a partir de um conjunto de normas e expectativas referentes ao sistema sexo/gênero/corpo (ou sexo/gênero/corpo/ alma, em alguns casos), imputado no nascimento ou gestação (MARANHÃO $\mathrm{F}^{\mathrm{o}}$, 2017, p. 171).

Essa engenhoca doutrinária se familiariza com um dispositivo da heteronorma que concebe a heteroafetividade / heterossexualidade como o complexo de expectativas, relações, normas, tradições, convenções e práticas sociais a serem descritas, prescritas e seguidas - colocando as não-heterossexualidades e não-heteroafetividades automaticamente em detrimento. Ambas maquinarias ideológicas se amalgamam em um dispositivo da cis-heteronorma, espécie de kit composto por códigos, protocolos e regulamentos que preceituam, ordenam, hierarquizam e decretam os caminhos de gênero e sexualidade que devem ser trilhados e os que devem ser dogmaticamente menosprezados e abandonados. Trata-se de uma labiríntica rede que abrange concepções, narrativas e ações imperativas que declamam e instituem padrões que silenciam perspectivas sexuais e de gênero discordantes; descrevem e prescrevem paradigmas e protótipos; (inter)ferem (n)a subjetividade e sensibilidade de gênero e sexual e propagam preconceito, discriminação, intolerância e violência a mulheres e pessoas não-cisgêneras e não-heterossexuais / não-heteroafetivas. 
Este mecanismo se relaciona com o que Foucault nomeia "o par "série de práticas/regime de verdade" que forma um "dispositivo de saber-poder que marca efetivamente no real o que não existe e submete legitimamente a demarcação do verdadeiro e do falso" (FOUCAULT, 2008, p. 27). De modo semelhante, Judith Butler explicou que a "verdade" sobre gênero e sexo é produzida por matrizes (possivelmente relacionáveis com os dispositivos foucaultianos) que interpelam e estabelecem as identidades, subjetividades e orientações que são consideradas socialmente legíveis e legítimas. Para Butler, a heterossexualização do desejo requer e promove a confecção de binariedades assimétricas e hierarquizáveis entre "feminino" e "masculino" os compreendendo como atributos localizáveis e coerentes de "macho" e "fêmea" (BUTLER, 2015, p. 44). Desta forma, se espera que a pessoa outorgada "macho" ou "fêmea" se comporte de modo "masculino" ou "feminino" através da conformidade a uma grade de inteligibilidade heterocentrada ou, mais que isso, a um dispositivo ou matriz cis-heteronormativa.

O dispositivo da cis-heteronorma tem como veículo e perpetrador uma certa "ideologia de gênesis". Como se nota na postagem do pastor Adir Eleotério de Almeida na internet,

nesta proposta "Ideológica", Deus cria a mulher e ordena o casal: "Sede férteis e multiplicai-vos"! Povoai e sujeitai toda a terra. Gênesis $1.28 \ldots$ Deus, portanto, criou os seres humanos à sua imagem, à imagem de Deus os criou: $M A C H O$ E FÊMEA OS CRIOU (Gênesis 1.27). Esta é a IDEOLOGLA DE GÊNESIS (ALMEIDA, itálico e caixa alta do pastor-autor, s/d).

O mito fundante (CHAUÍ, 2000) da ideologia de gênesis está na concepção de que "Deus criou macho e fêmea" tendo a mulher vindo da costela do homem para servir-lhe de auxiliadora (Gênesis 2:18-248; 1

\footnotetext{
Gênesis 2.18: "Deus disse: 'Não é bom que o homem esteja sozinho. Vou fazer para ele uma adjutora que esteja como diante dele". Gênesis 2. 20: "E Adão pôs os nomes a todo o gado, e às aves dos céus, e a todo animal do campo; mas para o homem não se achava adjutora que estivesse como diante dele". Gênesis 2.21: "Então o Senhor Deus fez cair um sono pesado sobre o homem, e este adormeceu, tomou uma de suas costelas, e colocou carne no seu lugar". Gênesis 2.22: "Então da costela que o senhor Deus tomou ao varão, formou a mulher, e trouxe ao varão". Gênesis 2.23: "E disse Adão: esta é agora osso dos meus ossos e carne da minha carne; esta será chamada varoa, porquanto do varão foi tomada". Gênesis 2.24: "Portanto deixará o homem a seu pai e sua mãe e unir-se-á a sua mulher, e serão os dois uma só carne".
} 
Coríntios 11:9) e como esposa devendo se submeter ao seu marido, "o cabeça da relação" e "cabeça e chefe da mulher" (1 Coríntios 11:3; Efésios 5:22-23). Assim como Eva teria sido criada para servir a Adão é possível pensarmos que, metaforicamente, a ideologia de gênesis serve ao dispositivo da cis-heteronorma como sagrada auxiliadora, proporcionando a este capital simbólico, o revestindo de reconhecimento e credibilidade e conferindo-lhe maior eficácia simbólica e performativa (BOURDIEU, 1992, 1996). Como a postagem acima sinaliza, o termo ideologia de gênesis tem sido utilizado para parodiar e confrontar a pretensa "ideologia de gênero". Mas afinal, o que seria a ideologia de gênero? ${ }^{9}$

\section{A ideologia de gênero e a igualdade de gênero}

A expressão "ideologia de gênero"10 é identificada em documentos eclesiásticos católicos desde a Conferência Episcopal do Peru realizada em 1998, como demonstram Sandra Duarte de Souza (2014 e 2018), Maria José RosadoNunes (2014 e 2015) e Fernanda Coelho (2016) ${ }^{11}$. Rosado-Nunes observa:

D. Orani (CNBB, 2014) menciona uma Nota da Conferência Episcopal do Peru, de abril de 1988 que, desde o título, alerta para os efeitos perniciosos dessa “ideologia de raiz marxista de ateia: 'La ideologia de género: sus peligros y alcances'. Retomando essa nota, o cardeal afirma que 'o sistema ideológico de gênero’ impõe a homens e mulheres comportamentos em desacordo com a 'natureza'. Nega, desta forma, o 'instinto natural' das meninas à maternidade e aos homens, sua 'necessidade de trabalhar fora de casa a fim de melhor sustentar a família'. A nota da Conferência dos Bispos do Peru talvez seja a primeira referência de um organismo oficial da igreja ao que vários documentos posteriores passarão a denominar assim (ROSADO-NUNES, 2014, p. 134).

\footnotetext{
9 Para mais informações acerca de re(l)ações entre ideologia de gênero e ideologia de gênesis, veja: MARANHÃO Fo, $2018 a$ e $2018 b$.

10 Além das autoras citadas no texto, sugiro ainda: SOUZA, 2016; SOUZA, MARANHÃO $\mathrm{F}^{\circ}, 2018$.

11 Coelho nota que o documento da Conferência Episcopal do Peru em 1998 "se utiliza de argumentos que desconstroem gênero e conformam uma ideologia por meio da distorção de trechos que evocam verdades sobre a natureza humana e a família natural" (COELHO, 2016, p. 10). Como deverá ficar perceptível neste artigo, quaisquer possibilidades de abalos estruturais na "família tradicional" cisgênera e heterossexual/afetiva e na noção de que "só existem homem e mulher" naturalmente criado/a por Deus, se tornam questões incômodas para os setores religiosos conservadores.
} 
A oposição entre "macho e fêmea" enunciada mais acima por Butler e Foucault a partir de seus conceitos de matriz e dispositivo está expressa nesta nota:

tem-se ouvido durante estes últimos anos a expressão 'gênero' e muitos imaginam que é apenas uma outra maneira de se referir à divisão da humanidade em dois sexos. Porém, por detrás desta palavra se esconde toda uma ideologia que pretende, precisamente, modificar o pensamento dos seres humanos acerca desta estrutura bipolar (VERITATIS, 2008, s/p).

A ideia de gênero presente na Conferência Episcopal do Peru manifesta uma distinção bipartida entre homem e mulher que pode ser chacoalhada perigosamente pelas reflexões e diálogos sobre gênero convencionados como "ideologia de gênero". O Documento do Conselho Pontifício para a Família publicado pelo Vaticano no ano 2000 decreta que "dentro de um processo que se poderia denominar de gradual desestruturação cultural e humana da instituição matrimonial, não deve ser subestimada a difusão de certa ideologia de "gênero"(gender)." Este arquivo avisa que a mesma procura instilar a ideia de que "ser homem ou mulher não estaria determinado fundamentalmente pelo sexo, mas pela cultura" e "com isto se atacam as próprias bases da família" (VATICANO, 2000 , s/p). Outro registro do Vaticano associa os estudos de gênero à ideologia de gênero: a "ideologia chamada gender theory" entende que "o gender de cada indivíduo resulta ser apenas o produto de condicionamentos e necessidades sociais, deixando, deste modo, de ter plena correspondência com a sexualidade biológica” (SÍNODO DOS BISPOS, 2014, p. 39).

Essas perspectivas coligem que gênero é sinônimo de "sexo biológico", conjunto de atributos cromossômicos e genitais que por sua vez influenciam em um "instinto natural" para que mulheres se tornem boas esposas, mães e donas-de casa enquanto homens atuam na esfera pública provendo o lar de suas necessidades materiais; que a locução ideologia de gênero é sinônima de estudos de gênero que engendram (parafraseando Simone de Beauvoir) que ninguém nasce com gênero, torna-se pertencente a um; ${ }^{12}$ e principalmente, que

12 Referência à frase "não se nasce mulher: torna-se mulher" (BEAUVOIR, 1949, vol. II, p. 15). O "tornar-se" mencionado pela autora exprime que tanto os papeis de gênero como a própria identidade / subjetividade são produtos de uma engenharia paulatina orientada por diferentes estímulos e que ocorre a partir de relações sócio-históricas. Não se é mulher, para a autora, simplesmente por ter nascido com corpo feminino: constrói-se a mulheridade durante a vida. 
estudar gênero causaria o extermínio da família tradicional. ${ }^{13}$

É importante nuançar que os estudos de gênero não buscam dizimar um modelo tradicional de família mas sim demonstrar a existência sóciohistórica de padrões de parentela diversos, inclusive no tempo presente; que o objetivo de se estudar sexualidade e gênero é o de problematizar relações opressivas e assimétricas e estimular a justiça e igualdade sexual e de gênero, assim como, de maneira interseccional, a equivalência regional, étnico-racial e referente a todos os marcadores sociais de igualdade e diferença, não existindo nada nos diálogos escolares e acadêmicos sobre gênero e sexualidade além de combater a desigualdade e educar para direitos iguais e cidadania; e que a maioria dos estudos de gênero não desconsideram ou negligenciam o aspecto biológico das pessoas, apenas enfatizam que para além deste há uma série de engrenagens que atuam na edificação do que é entendido costumeiramente como feminino, masculino, e em alguns casos, de gênero neutro, não-binário ou misto. Como pondera Joan Scott, gênero é elemento que constitui as relações sociais fundadas nas distinções percebidas entre os sexos, sendo a primeira maneira de dar significado às relações de poder:

O termo "gênero" torna-se, antes, uma maneira de indicar "construções culturais" - a criação inteiramente social de ideias sobre papeis adequados aos homens e às mulheres. Trata-se de uma forma de se referir às origens exclusivamente sociais das identidades subjetivas de homens e de mulheres. "Gênero" é, segundo essa definição, uma categoria social imposta sobre um

13 Certamente, relacionar os estudos de gênero (denominados por estes setores regressistas de ideologia de gênero ou teoria do gender, como é mais célebre na Itália e França) com uma destruição familiar é uma estratégia de deslegitimação e caricaturização dos mesmos, como indica Sara Garbagnoli (2014) segundo Luis Felipe Miguel (2016). Miguel nota que “a construção da doutrina católica contrária ao gênero começou no pontificado do papa Wojtyla (João Paulo II), sob o comando do prefeito da Congregação para a Doutrina da Fé, cardeal Ratzinger, que em 2005 sucederia a Wojtyla no papado, adotando o nome de Bento XVI. A partir dos anos 2000, delineia-se com clareza o adversário a ser combatido: aquilo que no Brasil recebeu o nome de "ideologia de gênero", mas que na França e na Itália costuma ser chamada de "teoria do gender" ("théorie du gender", "teoria del gender"), com o uso do inglês como forma de marcar sua origem alienígena. Embora se apoiando superficialmente na literatura feminista e queer, "trata-se de uma invenção polêmica dos meios conservadores católicos que visa caricaturizar e, assim, deslegitimar um campo de estudos" (GARBAGNOLI, 2014, p. 149)" (MIGUEL, 2016, p. 598). Além disso, na França, quem se opõe às políticas de justiça de gênero costuma usar tanto "théorie du genre" quanto "du gender". O uso da forma inglesa objetiva sinalizar o caráter "estrangeiro" do conceito, todavia é o próprio conceito de gênero (genre) que é considerado estrangeiro (estadunidense, no caso) e não necessariamente a forma inglesa da palavra. Para aprofundamentos, veja: BERENI, TRACHMAN, 2014. 
"Gênero é pedofilia, zoofilia e necrofilia": a destruição da família 101 $e$ as ideologias de gênero e gênesis nos discursos de Magno Malta

corpo sexuado. Com a proliferação dos estudos sobre sexo e sexualidade, "gênero" tornou-se uma palavra particularmente útil, pois oferece um meio de distinguir a prática sexual dos papéis sexuais atribuídos às mulheres e aos homens (SCOTT, 1995, p. 75).

Para a autora, as categorias homem e mulher sugerem "que o masculino e o feminino não são características inerentes e sim construções subjetivas (ou fictícias)" implicando "que o sujeito se encontra num processo constante de construção" (SCOTT, 1995, p. 82). Scott entende gênero como edificação sócio-histórica que constitui os vínculos sociais moldados a partir das diferenças percebidas entre os sexos - e tais dissimilitudes são identificadas nos corpos. Enquanto construção histórica e social que corporifica as relações de poder, o gênero tem sido persistentemente utilizado para dar eficácia e consistência a hierarquizações e opressões (de gênero) em âmbitos diversos das tradições monoteístas judaico-cristãs e islâmicas. De modo símile à Scott, Judith Butler historiciza, contextualiza e problematiza corpo, sexo e gênero, demonstrando serem arquiteturas sócio-históricas contaminadas por relações de poder e questionando, dentre outras coisas, a normalização e normatização operadas a partir da naturalização e biologização dos corpos e das identidades. Para Butler, há uma ordem compulsória social que prega a coerência entre corpo, sexo, gênero e desejo em um âmbito heteronormativo e é necessário desmontar tal ordem, desobrigando desejo, corpo, gênero e sexo de serem encaixotados dentro de uma (suposta) linearidade e coerência (BUTLER, 2008). Já para Anne Fausto-Sterling não só o gênero é socialmente construído como o sexo biológico também, visto que a própria medicina se utiliza de critérios culturais para definir o sexo de bebês (FAUSTO-STERLING, 2012), e para Beatriz/ Paul Preciado, gênero relaciona-se com o transbordamento do sujeito através de suas margens abjetas, o que é analisado pelos estudos pós-feministas e queer (PRECIADO, 2002). Em todas estas perspectivas gênero é sócio-historicamente construído, como observa com temeridade o documento do Vaticano supramencionado - ainda que o fator biológico também seja levado em conta pelos estudos de gênero: estes não negam os elementos biológicos, apenas discordam do determinismo biológico que prega que a partir do sexo outorgado no nascimento todo o destino da pessoa estaria traçado. ${ }^{14}$

\footnotetext{
14 Importa realçar que o fator biológico não é desconsiderado pelos estudos de gênero, contudo, também não é compreendido na mesma perspectiva do Vaticano, e nem tampouco no viés de uma "leitura ideológica de gênesis". Fausto-Sterling, por exemplo, observa que não apenas o gênero, mas o sexo igualmente apresenta-se de modo polissêmico: para além da polaridade macho e fêmea, a autora considera a existência de cinco sexos. Assim, tanto o gênero quanto o sexo ultrapassam qualquer concepção binária.
} 
Em termos acadêmicos a expressão ideologia de gênero foi utilizada pela primeira vez - em 2004 - pela socióloga brasileira Heleieth Saffioti, para quem gênero "carrega uma dose apreciável de ideologia" (SAFFIOTI, 2004, p. 136): a ideologia patriarcal que promove a opressão masculina sobre as mulheres procurando naturalizar a subserviência feminina e a desigualdade de gêneros (não a diferença, mas a desigualdade). Seguindo a assertiva da autora, é plausível conjecturarmos que ao buscar instituir duas únicas possibilidades legítimas de gênero (o masculino e o feminino, o primeiro englobando/ oprimindo o segundo de forma patriarcal), a ideologia de gênesis atua legitimando a ideologia de gênero: sentencia que há somente dois sexosgêneros criados e hierarquizados pelo Deus-Pai, em que a mulher deve seguir subserviente ao homem e as subjetividades / sensibilidades sexuais e de gênero dissonantes devem ser relegadas ao sheol (inferno) de onde não deveriam ter saído. Assim, qualquer caminho de gênero que não estiver em conformidade com a ideologia de gênesis - sagrada auxiliar do dispositivo da cisheteronorma - é considerado abominação a Deus e indigno de legitimidade e credibilidade. É necessário destacar que a concepção de Saffioti sobre ideologia de gênero não é nada parecida com o que é observado pela Conferência Episcopal do Peru (1998) e documentos eclesiásticos posteriores, nem tampouco com o que setores regressistas mal-intencionados e intelectualmente desonestos tem atribuído falaciosamente à expressão, celebrando-na como promotora da transexualidade e da homossexualidade na infância - ou ainda da obrigatoriedade de se utilizar sanitários do sexo oposto, da promiscuidade, pedofilia, aborto, estupro, zoofilia, etc. De modo símile a Malta, Dom Antônio Keller, por exemplo, julgou que a partir da ideologia de gênero a sociedade estaria "fundada na mais absoluta permissividade sexual, já que a cada um caberá estabelecer seu próprio gênero, segundo as tendências homossexuais, transexuais, bissexuais ou outras" e que "estão abertas as portas para as já conhecidas 'opções sexuais' possíveis, bem como para qualquer outro tipo de opção, como por exemplo a zoofilia, a pedofilia e o que se quiser criar” (KELLER, 2014), confundindo orientações sexuais e afetivas com tendências e parafilias (preferências sexuais doentias / transtornos da sexualidade). ${ }^{15}$ Como observam Toni Reis e Edla Eggert,

15 Sobre tal pronunciamento de Keller, acessar também: Sandra Duarte de SOUZA, 2014, 2018. 
"Gênero é pedofilia, zoofilia e necrofilia": a destruição da família 103 $e$ as ideologias de gênero e gênesis nos discursos de Magno Malta

criou-se uma falácia apelidada de "ideologia de gênero", que induziria à destruição da família "tradicional", à legalização da pedofilia, ao fim da "ordem natural" e das relações entre os gêneros, e que nega a existência da discriminação e violência contra mulheres e pessoas LGBT comprovadas com dados oficiais e estudos científicos. Utilizou-se de desonestidade intelectual, formulando argumentos sem fundamentos científicos e replicando-os nas mídias sociais para serem engolidos e regurgitados pelos fiéis acríticos que os aceitam como verdades inquestionáveis. Utilizou-se também de uma espécie de terrorismo moral, atribuindo o status de demônio às pessoas favoráveis ao respeito à igualdade de gênero e diversidade sexual na educação, além de intimidar profissionais de educação com notificações extrajudiciais com ameaça de processo contra quem ousasse abordar esses assuntos na sala de aula. Criou-se um movimento para "apagar" o assunto gênero do currículo escolar (REIS, EGGERT, 2017, p. 20).

Tais premissas falaciosas apelam para o pretenso "fim da família natural" apostando na instituição de um sentimento de pavor, caos e pânico coletivo - claros estimuladores de preconceito, intolerância e violência. Fernanda Coelho contempla uma fobia religiosa de gênero (COELHO, 2017) ${ }^{16}$ enraizada na condenação da (suposta) ideologia de gênero que "ocorre por meio da mistura de conceitos, da distorção e ambiguidade de informações e da utilização de noções que despertam pânico moral" (COELHO, 2016, p. 10) na população, "reforçando os códigos de sentido desta em oposição às ameaças à identidade brasileira e, por conseguinte, à ordem e ao bem comum" (COELHO, 2017, p. 275). Tainah Biela Dias observa que um "temor relacionado ao fim da espécie humana é acionado porque, neste imaginário religioso, somente a reprodução biológica fruto da relação sexual entre um homem e uma mulher é compreendida como legítima" (DIAS, 2017, p. 65), e para Coelho, "ao conclamarem a família brasileira, sempre entendida em sua configuração biologizante (...) de macho e fêmea, tida como a única possibilidade correta e legítima, o discurso religioso desqualifica outras orientações sexuais e identidades de gênero" (COELHO, 2017, p. 275).

Malta, dentre outros políticos da ala extremista religiosa, reproduz ${ }^{17}$ equações envolvendo "os tentáculos da esquerda" retirados do poder por Deus (BRASIL, 2018) e um suposto "comunismo/marxismo" que estaria por assolar o país, vinculando o extermínio da família à pedofilia, zoofilia,

16 Sugiro ainda: COELHO, 2021; COELHO; SANTOS, 2016.

17 A nota da Conferência Episcopal Peruana já sublinhava a relação entre comunismo, gênero e feminismo, por exemplo. 
necrofilia e instaurando o pavor social às necessárias discussões sobre gênero e sexualidade. Esta arquitetura da destruição familiar fomentada por pessoas que entendem fundamentais os diálogos respeitosos sobre gênero e sexualidade em ambientes educativos se vale falaciosamente da construção do imaginário social do "inimigo", como sinalizado por Magali do Nascimento Cunha:

Exércitos precisam de inimigos. A teologia de um Deus guerreiro e belicoso sempre esteve presente na formação fundamentalista dos evangélicos brasileiros, compondo o seu imaginário e criando a necessidade da identificação de inimigos a serem combatidos (CUNHA, 2013).

Tal discurso bélico se conecta com a teologia da batalha espiritual, em que

Satanás e seus demônios, diabos, capetas e zarapelhos fazem parte de uma força-tarefa obstinada em causar a derrota dos seres humanos, devendo ser combatidos com "unhas e dentes" espirituais. Para efetuar a peleja contra o exército infernal, soldados/as especialistas, forjados/as através de cultos, reuniões celulares, ministérios e eventos - bases de treinamento e operações táticas - utilizam a intercessão (exorcismo / desobsessão / desencapetamento) como bazuca espiritual para aniquilar entidades convocadas para a guerra como Exuscaveiras, Pombagiras, Tranca-ruas, Maria Padilhas, Capa-pretas, Capirotos, Carochos, Cramulhões, Coisas-ruins, Caramujos-no-lombo e outras sobras das Trevas. Tais esforços são responsáveis por retirar Lúcifer e seus tinhosos do corpo e da alma dos/ as crentes bem treinados/as (MARANHÃO Fo , 2012, p. 134; 2013, p. 108).

A ideologia de gênero, inimigo "espiritual" a ser digladiado pela ideologia de gênesis, possui entre suas "diabólicas" hostes mulheres indóceis aos homens, pessoas não-cisgêneras/transgêneras $\frac{18}{\text { e pessoas }}$ não-heterossexuais/afetivas. Estes adversários temerários são percebidos como periclitantes pois podem desestabilizar e desestruturar a suposta "ordem natural das coisas" em que há dois únicos sexos-gêneros (o macho/homem cisgênero e a fêmea/mulher cisgênera) ${ }^{19}$ com uma

18 Transgeneridade não é vista aqui como "identidade" específica mas condição sócio-política de transgressão de expectativas e convenções sociais referentes ao sistema sexo-gênero outorgado no nascimento (LANZ, 2014; MARANHÃO Fº, 2014).

19 Cisgeneridade, "do grego cis: reto, do mesmo lado, em conformidade com, remete à pessoa cisgênera, cissexual ou simplesmente cis: aquela que se sente confortável, bem ajustada, que concorda com o sistema sexo-gênero binário (mulher ou homem) que lhe foi atribuído/outorgado no nascimento ou antes, na gestação. Ao contrário do que se pode pensar, a pessoa cisgênera não é necessariamente heterossexual: pode ter qualquer orientação sexual ou afetiva. Assim, há mulheres e homens cis que podem ser homossexuais, bissexuais, assexuadas/os, pansexuais e heterossexuais - dentre outras autodeclarações possíveis” (MARANHÃO F, 2014, p. 716). 
"Gênero é pedofilia, zoofilia e necrofilia": a destruição da família 105 $e$ as ideologias de gênero e gênesis nos discursos de Magno Malta

única orientação sexual-afetiva (a hétero) e o masculino englobando hierarquicamente o feminino - como espera-se, aliás, da leitura ipsis litteris de Gênesis 2: 18-25, em que Eva é moldada a partir da costela de Adão para servir-lhe de auxiliar. A teologia da batalha espiritual - que reveste como armadura a ideologia de gênesis - se mescla a outra, a teologia do domínio, que "pensa promover uma espécie de recristianização da sociedade pelo 'Alto', quer dizer, pela via político-partidária e pela mídia eletrônica”, como confere Ricardo Mariano (1999, p. 44). Encontramos exemplos de beligerantes discursos parlamentares envolvendo as ideologias de gênesis e de gênero em diversos momentos de nossa história recente, como por exemplo nas discussões acerca da utilização de termos relacionados à diversidade sexual e de gênero no Plano Educacional de Educação (PNE), em 2014. ${ }^{20}$

\section{A marcial e dominadora ideologia de gênesis na política}

Diversos políticos da ala retrógrada ${ }^{21}$ se pronunciaram em reunião

20 A expressão ideologia de gênero ressurgiu com potência a partir dos debates que envolveram o Plano Nacional de Educação (PNE) que tramitou no Congresso Nacional desde 2010 e só foi sancionado pela Presidenta Dilma Vana Rousseff em 25 de junho de 2014. Os diálogos acerca do PNE bem como dos Planos Municipais de Educação (PMEs), por sua vez, foram fomentados a partir da Conferência Nacional da Educação Básica (CONEB) de 2008 e das Conferências Nacionais de Educação (CONAE) de 2010 e 2014, bem como de suas respectivas instâncias estaduais e municipais. Exemplarmente, o Documento Final da CONEB realça a necessidade de "uma educação com qualidade social que (...) vise a superação das desigualdades sociais, raciais, de gênero, de idade e de orientação sexual" (BRASIL, 2008, p. 1), e de modo símile, o Documento Final da CONAE 2010 é recheado de remissões à diversidade sexual e de gênero, como na proposta a se "inserir e implementar na política de valorização e formação dos/das profissionais da educação" a "discussão de gênero e diversidade sexual, na perspectiva dos direitos humanos, quebrando os paradigmas hoje instituídos e adotando para o currículo de todos os cursos de formação de professores/ as um discurso de superação da dominação do masculino sobre o feminino, para que se afirme a constituição de uma educação não sexista". (BRASIL, 2010, p. 143). Para um histórico sucinto dos embates em torno da educação como direito fundamental no Brasil e relacionados a gênero e sexualidade: REIS, EGGERT, 2017.

21 Em 2012 foram homologadas as Diretrizes Nacionais para a Educação em Direitos Humanos, fazendo referências a gênero e orientação sexual e afirmando que "todas as pessoas devem ter a possibilidade de usufruírem de uma educação não discriminatória e democrática, independente do seu sexo, orientação sexual e identidade de gênero, entre outras características" (BRASIL, 2012). Este alvissareiro horizonte de avanços relativos aos direitos iguais, entretanto, se deparou com regressistas resistências. Dentre os segmentos sociais resistentes à justiça e igualdade de gênero, destacam-se algumas alas reacionárias dentro do catolicismo e das igrejas evangélicas, muitas delas posicionadas no cenário político e midiático brasileiro. 
da Comissão Especial do PNE realizada em 8 de abril de $2014 .{ }^{22} \mathrm{O}$ pastor-celebridade - ou popstor - Marco Feliciano (Partido Social Cristão / PSC-SP) ${ }^{23}$ redarguiu que a presumida "ideologia de gênero" seria "uma construção social da imagem sobre o ser humano, ou seja, o ser humano nasce um ser amorfo. Ele vai se descobrir homem ou mulher depois, quando tiver certa idade" (BRASIL, 2014, s/n). É ostensivo que a preocupação esteja em se deformar o molde criado por Deus: macho $e$ fêmea, ideia reforçada por Pastor Eurico (Partido Socialista Brasileiro / PSB-PE), que complementou Feliciano:

sempre usei essa expressão gênero como identificação de homem e mulher. Mas partindo desse princípio, que agora é oriundo de outras partes do planeta, automaticamente é uma desconstrução daquilo que nós sempre defendemos, que é exatamente a questão homem e mulher e principalmente a questão família no contexto de macho e de fêmea (BRASIL, 2014, s/n).

A argumentação dos pastores-deputados ${ }^{24}$ era de que a diretriz original do PNE instigaria a "ideologia de gênero" promotora da "ameaça à família", precisando ser combatida pela verdade expressa na Bíblia (Deus criou macho e fêmea) - o que se assemelha à Nota da Conferência Episcopal do Peru (1988) comentada por D. Orani (2014), para quem a ideologia de gênero negaria "o instinto natural das meninas à maternidade" e aos homens sua necessidade biológica de ser o arrimo da família atuando no espaço público. A amplificada campanha movida por setores regressistas católicos e evangélicos ${ }^{25}$

22 Demonstrando que a ala retrógrada supramencionada não era composta apenas de segmentos evangélicos superconservadores mas também católicos (dentre outros), cerca de um mês antes, em 10 de março de 2014, no período em que a Casa revisora debatia o substitutivo do PNE elaborado pela Câmara, o famigerado padre Paulo Ricardo havia publicado em seu site: "Prezado Amigo, está em fase final de tramitação na Câmara Federal o PL 8035/2010, de origem do executivo, que cria o PNE - Plano Nacional de Educação para os próximos 10 anos. O pedido é simples. É absolutamente necessário que você ligue para a lista de onze parlamentares abaixo e solicite que na votação do PL, no próximo dia 19 de março, seja mantida no artigo 2o do projeto, a redação aprovada no Senado. Por favor, escreva este pedido numa única mensagem, c/c oculta, para todos os deputados integrantes da lista e também para as lideranças dos partidos, cujos e-mails encontram-se no final deste texto. A família brasileira agradece" (CHRISTO NIHIL PRAEPONERE, 2014, s/n).

23 Parlamentares e candidatos/as podem mudar de partido político como permite a Constituição Federal. Procurei indicar aqui a sigla relacionada ao momento político em questão.

24 Para dados recentes sobre a Frente Parlamentar Evangélica (FPE), coletivo que agrega estes e outros políticos evangélicos, recomendo: DIP, 2018.

25 A "ideologia de gênero" se celebrizou através de líderes políticos e religiosos como Silas Malafaia, Júlio Severo, Marco Feliciano (PSC-SP), Eros Biondini (PROS-MG), Pastor 
"Gênero é pedofilia, zoofilia e necrofilia": a destruição da familia 107 $e$ as ideologias de gênero e gênesis nos discursos de Magno Malta

(e em menor monta, espíritas) contra o que se denominou "ideologia de gênero" culminou, dentre outras coisas, na exclusão das diretrizes do PNE e PMEs que enfatizavam a promoção da igualdade de gênero e de orientação sexual, regional e racial.

Andrea Dip nota que este espírito reacionário tem se corporificado, por exemplo, no Estatuto da Família (PL 6.583/2013) que tramitou no Senado no final de 2017 e reconhece a família "como 'o núcleo social formado a partir da união entre um homem e uma mulher por meio de casamento ou união estável, ou ainda por comunidade formada por qualquer dos pais e seus descendentes", ainda que o último Censo do IBGE mostre que outros arranjos familiares constituem 50,1\% dos lares brasileiros, e que há 19 laços de parentesco (DIP, 2018). E a milícia ideológica de gênesis continua encontrando um ambiente hospitaleiro na Câmara dos Deputados Federais atualmente. No dia 11 de julho de 2018 o Cabo Daciolo (Patriota / PATRI-RJ) apresentou Projeto de Lei (PL 10577/2018) para modificar o art. $3^{\circ}$ da Lei no 9.394 de 20 de dezembro de 1996 (que determina as diretrizes e bases da educação nacional) e "proibir a disseminação da ideologia de gênero nas escolas do Brasil". Esta objetivaria "perverter a família natural", sendo "a suposta orientação sexual" um "comportamento adquirido por falta de referencial paterno ou materno ou mesmo pela influência do meio" e "resultado de atitudes adultas de pedófilos que tentam perverter crianças indefesas". Complementou: "Criou Deus o homem à sua imagem, à imagem de Deus o criou; homem e mulher os criou. Deus os abençoou, e lhes disse: 'Sejam férteis e multipliquem-se! Encham e subjuguem a terra!" (Gênesis 1:27,28) (BRASIL, 2018, s/p).

Como lamentavelmente percebemos, os/as ideólogos/as de gênesis persistem, assim como faz Magno Malta, confundindo os estudos de gênero com uma suposta ideologia relacionada à perversão, pedofilia, necrofilia, zoofilia e outros elementos que criam um arcabouço propício ao desenvolvimento de um sentimento de pânico moral, além de preconceito, desigualdade, discriminação, intolerância, injustiça e violência. Identificado o azedume rançoso destas concepções teocráticas e antidemocráticas, cabe perguntar: Após tal tempestade retrógrada virá enfim a bonança? Apesar destes parlamentares reacionários amanhã haverá de ser outro dia? Não sendo

Eurico (PSB-PE) e católicos como Jair Messias Bolsonaro (PSL-RJ) e Padre Paulo Ricardo, todos célebres pela renitência aos direitos relacionados à saúde da mulher e de pessoas não-hétero e não-cisgêneras, e por suas concepções sexistas, misóginas e, em alguns casos (como o de Bolsonaro e Feliciano), consideradas racistas. 
ainda possível responder a estas perguntas e lembrando que a esperança é a última que morre, segue uma mais simples: por que é tão importante estudar / dialogar sobre isonomia sexual e de gênero?

\section{Considerações inconclusivas (crendo que amanhã há de ser outro dia)}

Setores regressistas observam que "gênero é uma ficção" e "ideologia criada sobre algo que não existe", havendo só "dois sexos" (homem e mulher, e ambos héteros). Entretanto, gênero é real: este conceito é produto de diálogos sociais (e acadêmicos) profundos e robustos, fundados em parâmetros científicos de produção e elaboração de conhecimentos, procurando dar forma ao que é considerado feminino e masculino, além de mesclas e não-binariedades de gênero. Gênero dá sentido e significado a vivências reais, afetivas e sensíveis, conferindo inteligibilidade a corpos, subjetividades, narrativas, ações, memórias e emoções e percebendo processos culturais e sócio-históricos que descrevem, prescrevem e legitimam estruturas de poder. Sabemos, ainda, que a discriminação e violência contra mulheres (especialmente as consideradas inobedientes pelo dispositivo da cis-heteronorma e pela ideologia de gênesis) e pessoas não-cisgêneras e não-hétero é alargada na sociedade e ocultar discussões sobre tais temas é (re)produzir mais violência estrutural e institucional. O extermínio dos diálogos sobre sexualidade e gênero pode conduzir, por exemplo, à evasão escolar, acarretando menor qualificação profissional, desemprego, prostituição, vulnerabilidade sócio-econômica, etc. A ideologia de gênesis, em casos extremos, pode conduzir pessoas transgêneras (dentre outras) à morte não só metafórica/subjetiva como literal (MARANHÃO Fº, 2014, 2016a, 2017).

Por estes e outros motivos navegar falando sobre gênero, sexualidade e afetividade é preciso. Também é necessário que o próximo Plano Nacional de Educação, bem como a Base Nacional Comum Curricular (BNCC), Planos Municipais de Educação (PMEs) e Projetos de Lei (PLs), dentre outros documentos oficiais, estimulem debates de forma franca e respeitosa, enfrentando o preconceito, hostilidade e intolerância, bem como a evasão escolar por conta de opressão religiosa. A partir de uma educação justa, igualitária, inclusiva e acolhedora a todas as existências será possível atuarmos na profanação do dispositivo (AGAMBEN, 2014) da cis-heternorma que tem promovido a discriminação e a violação de Direitos Humanos. Conversar sobre gênero em contextos escolares e acadêmicos - bem como em quaisquer 
ambientes, inclusive religiosos - não tem nada a ver com ideologia de gênero (e tudo de pernicioso que a ela é associado de forma intelectualmente desonesta) mas sim com equivalência de direitos, implicando em diminuir ou suprimir as assimetrias entre os gêneros e as orientações sexuais/afetivas. Promover a paridade e justiça de gênero não tem como intuito anular as diferenças entre as pessoas, mas sim, garantir que tais diferenças não convirjam em desigualdade e em opressão.

É necessário destacar, por fim, que os cristianismos não formam um bloco homogêneo. Assim como há setores regressistas e que promovem a discriminação, intolerância e violência a mulheres, pessoas não-cisgêneras e não-hétero, existem alas progressistas católicas e evangélicas. ${ }^{26} \mathrm{E}$ claro, além de tais setores, há muitos outros coletivos e indivíduos cristãos que não se sentem nem um pouco representados por discursos que veiculam discriminação, desigualdade, injustiça e violência de gênero/sexual. É preciso que se diga não à ideologia de gênesis e sim à igualdade de gênero: a educação deve ser libertadora e respeitosa a todas as diversidades assim como a laicidade do Estado deve ser devidamente assegurada.

Referências

AGAMBEN, Giorgio. O amigo \& O que é um dispositivo? Chapecó: Argos, 2014.

BEAUVOIR, Simone de. Le deuxième sexe. 2 v. Paris: Gallimard, 1949.

BERENI, Laure, TRACHMAN, Mathieu. Le genre, théories et controverses, Paris, Vie des idées - PUF, 2014.

BOURDIEU, Pierre. A economia das trocas linguísticas (o que falar quer dizer). São Paulo: EDUSP, 1996.

A economia das trocas simbólicas. São Paulo: Editora Perspectiva, 1992.

BUTLER, Judith. Problema de gênero: feminismo e subversão da identidade. Rio de Janeiro: Civilização Brasileira, 2008.

26 Entre as primeiras, destacam-se institucionalmente movimentos como o Católicas pelo Direito de Decidir, que atua em pautas referentes ao direito da mulher sobre seu próprio corpo; movimentos LGBT+ e teólogas católicas feministas. Há alas progressistas evangélicas como os movimentos de pastores e pastoras a favor do desarmamento e a favor do aborto, as Evangélicas pela Igualdade de Gênero (EIG) e o movimento Jesus cura a homofobia. Mulheres católicas e evangélicas formam o coletivo Feministas Cristãs. Há ainda as igrejas inclusivas que tem nas suas lideranças pessoas não-hétero e não-cisgêneras (MARANHÃO Fº, 2014, 2015, 2016b). 
CHAUÍ, Marilena. Brasil. Mito fundador e sociedade autoritária. São Paulo: Fundação Perseu Abramo, 2000.

COELHO, Fernanda Marina Feitosa; SANTOS, Naira Pinheiro dos. A mobilização católica contra a "ideologia de gênero" nas tramitações do Plano Nacional de Educação brasileiro. Religare, vol. 13, n. 1, p. 27-48, 2016.

. Ideologia de gênero: os porquês e suas consequências no contexto do plano nacional de educação Brasileiro 2014-2024. Mandrágora, v.23. n. 2, p. 247-279, 2017.

. Ideologia de gênero - origens e consagração no Brasil. In: MARANHÃO $\mathrm{F}^{\circ}$, Eduardo Meinberg de Albuquerque; SAEZ, Oscar Calavia (Orgs.) ANAIS do II Simpósio Internacional da ABHR, XV Simpósio Nacional da ABHR. História, gênero e religião: Violências e Direitos Humanos. UFSC, Florianópolis, SC, 2016.

“Menino é menino, menina é menina”: Religião e ideologia de gênero no Plano Nacional de Educação. Florianópolis: AMAR / FOGO, 2021.

CUNHA, Magali do Nascimento. O lugar das mídias no processo de construção imaginária do "inimigo" no caso de Marco Feliciano. Comunicação, Mídia e Consumo. São Paulo, v. 10, n. 29, p. 51-74, 2013.

DELEUZE, Gilles. ¿Que és un dispositivo? In: DELEUZE, Gilles, et al. Michel Foucault, filósofo. Barcelona: Gedisa, 1990, pp. 155-161.

DIP, Andrea. Em nome de quem? A bancada evangélica e seu projeto de poder. Rio de Janeiro: Civilização Brasileira, 2018.

DIAS, Tainah Biela. A defesa da família tradicional e a perpetuação dos papeis de gênero naturalizados. Mandrágora, v.23, n.1, p. 49-70, 2017.

FAUSTO-STERLING, Anne. Sex / Gender: biology in a social world. Lillington, Carolina do Norte: Routledge, 2012.

FOUCAUlT, Michel. Nascimento da Biopolítica. São Paulo: Martins Fontes, 2008. 1988.

História da sexualidade, vol. 1. A vontade de saber. Rio de Janeiro: Edições Graal,

Sobre a História da sexualidade. In: FOUCAULT, Michel. Microfísica do poder. Rio de Janeiro: Graal, 2000. p. 243 - 270.

GARBAGNOLI, Sara; PREARO, Massimo. La croisade "anti-genre". Du Vatican aux manifs pour tous. Paris, Textuel, Coll. Petiteencyclopédie critique, 128 p., 2017.

LANZ, Letícia. O corpo da roupa: a pessoa transgênera entre a transgressão e a conformidade com as normas de gênero. Dissertação (Mestrado em Sociologia). Programa de Pós-graduação em Sociologia. Universidade Federal do Paraná, Curitiba, 342 p., 2014.

MARANHÃO $F^{\circ}$, Eduardo Meinberg de Albuquerque. A Bola de Neve avança, o Diabo retrocede: Preparando davis para a batalha e o domínio através de um Marketing de Guerra Santa em trânsito. REVER - Revista de Estudos da Religião (PUC-SP), ano 12, n. 2, p. 124- 143, 2012. 
"Gênero é pedofilia, zoofilia e necrofilia": a destruição da família 111 $e$ as ideologias de gênero e gênesis nos discursos de Magno Malta

A grande onda vai te pegar: Marketing, espetáculo e ciberespaço na Bola de Neve Church. São Paulo: Fonte Editorial, 2013.

" "A travesti morreu, mas carrego ela no caixão" e outras histórias vivas: conversão, transfobia religiosa e morte. Revista Brasileira de História das Religiões. ANPUH, Ano X, n. 29, 2017.

; COELHO, Fernanda Marina Feitosa; DIAS, Tainah Biela. "Fake news acima de tudo, fake news acima de todos": Bolsonaro e o "kit gay", "ideologia de gênero" e fim da "família tradicional". Correlatio, v. 17, n. 2, p. 65-90, 2018.

"Matando uma leoa por dia": ideologia de gênero e de gênesis na "cura" de travestis. Correlatio, v.17, n.2, p.107-148, 2018a.

"Menino veste azul e menina, rosa" na Educação Domiciliar de Damares Alves: As ideologias de gênero e de gênesis da "ministra terrivelmente cristã" dos Direitos Humanos. Revista Brasileira de História das Religiões, ANPUH, ano XII, n. 34, 2019.

( $\mathrm{Re} / \mathrm{des})$ conectando gênero e religião. Peregrinações e conversões trans* e extrans* em narrativas orais e do Facebook. Tese de Doutorado apresentada ao Programa de Pós Graduação em História Social da Universidade de São Paulo. São Paulo, 2014.

Sai desse corpo que esse caminho não te pertence! Pessoas trans* e ex-trans* em (re/des)caminhos de gênero, corpo e alma. Revista Brasileira de História das Religiões. ANPUH, Ano VIII, n. 24, p. 197-219, $2016 a$.

Teologia queer e cristrans: Transições teológicas na Igreja da Comunidade Metropolitana (ICM). Mandrágora, v.22. n. 2, p. 149-193, 2016 b.

"Uma Igreja dos Direitos Humanos" onde "promíscuo é o indivíduo que faz mais sexo que o invejoso e inveja é pecado": Notas sobre a identidade religiosa da Igreja da Comunidade Metropolitana (ICM). Mandrágora, São Bernardo do Campo, v.21. n. 2, p. 5-37, 2015.

"Um tapa na cara pra quem diz que cura gay não existe": A ideologia de gênesis em Cleycianne, Lady Gaga e Marco Feliciano. Religare, v.15, n.2, p. 612-651, 2018 b.

MARIANO, Ricardo. Neopentecostais. Sociologia do novo pentecostalismo no Brasil. São Paulo: Loyola, 1999.

MIGUEL, Luis Felipe. Da "doutrinação marxista" à "ideologia de gênero" - Escola Sem Partido e as leis da mordaça no parlamento brasileiro. Direito \& Práxis. Vol. 07, N. 15, 2016.

PRECIADO, Beatriz/Paul. Manifiesto Contrasexual. Barcelona: Opera Prima, 2002.

REIS, Toni; EGGERT, Edla. Ideologia de gênero: uma falácia construída sobre os planos de educação brasileiros. Educação \& Sociedade. Vol. 38, núm. 138, 2017.

ROSADO-NUNES, Maria José Fontelas. A “ideologia de gênero” na discussão do PNE: a intervenção da hierarquia católica. Horizonte, Belo Horizonte, v. 13, n. 39, p. 1237-1260, 2015.

Gênero: uma questão incômoda para as religiões. In: SOUZA, Sandra Duarte de, SANTOS; Naira Pinheiro dos. Estudos feministas e religião: Tendências e debates. Curitiba: Editora Prismas, 2014, p.129-147. 


\section{Eduardo Meinberg de Albuquerque Maranhão $F^{o}$.}

SAFFIOTI, Heleieth. Gênero, patriarcado, violência. São Paulo: Fundação Perseu Abramo, 2004.

SCOTT, Joan. Gênero: uma categoria útil de análise histórica. Educação \& Realidade, v. 20, n. 2, p. 71-99, 1995.

SOUZA, Odair de. A construção do Plano Municipal de Educação no município de Paulo Lopes/SC e sua interface com a religião. TCC (Especialização em Gênero e Diversidade na Escola). Orientação de Eduardo Meinberg de Albuquerque Maranhão Fo. Programa de Pós-graduação em Gênero e Diversidade na Escola. Universidade Federal de Santa Catarina, Florianópolis, p. 61, 2016.

MARANHÃO Fo ${ }^{\circ}$ Eduardo Meinberg de Albuquerque. Gênero e Diversidade na Escola ou ideologia de gênero? Reações religiosas a um Plano Municipal de Educação de Santa Catarina. Poder \& Cultura, 2018.

SOUZA, Sandra Duarte de. "Não à ideologia de gênero!". A produção religiosa da violência de gênero na política brasileira. Estudos de Religião. Vol. 28. nº 2, 2014.

"Não à ideologia de gênero!” A produção religiosa da violência de gênero na política brasileira. In: MARANHÃO Fo , Eduardo Meinberg de Albuquerque; SÁEZ, Oscar Calavia (Orgs.). História, Gênero e Religião: Violências e Direitos Humanos (Vol. 1). Coleção ABHR. Florianópolis: ABHR / Fogo, 2018, p. 153-172.

\section{Internet}

ALMEIDA, Adir Eleotério de. Espaço do Pregador (sem data). Disponível em: www. espacopregador.com/2018/03/a-ideologia-de-genero-e-ideologia-de.html. Acesso em 02 jun. 2018.

Acusado de abuso por CPI da Pedofilia denuncia senador Magno Malta (16/10/2018). Século Diário. Disponível em: http://seculodiario.com.br/public/jornal/materia/acusado-de-abusopor-cpi-da-pedofilia-denuncia-senador-magno-malta. Acesso em 02 dez. 2018.

BRASIL. Magno Malta - ES. Senado Federal. Disponível em: https://www25.senado.leg.br/ web/senadores/senador/-/perfil/631. Acesso em 02 dez. 2018.

BRASIL. Senado. Disponível em: www25.senado.leg.br. Acesso em 02 dez. 2018.

BRASIL. Senado. Pronunciamento de Magno Malta em 18/10/2007. Disponível em: https:// www25.senado.leg.br/web/atividade/pronunciamentos/-/p/texto/370913. Acesso em 02 dez. 2018.

BRASIL. Senado. Pronunciamento de Magno Malta em 11/11/2009. Disponível em: https:// www25.senado.leg.br/web/atividade/pronunciamentos/-/p/texto/382649. Acesso em 02 dez. 2018.

BRASIL. Senado. Pronunciamento de Magno Malta em 18/12/2008. Disponível em: https:// www25.senado.leg.br/web/atividade/pronunciamentos/-/p/texto/377545. Acesso em 02 dez. 2018. 
"Gênero é pedofilia, zoofilia e necrofilia": a destruição da família 113 $e$ as ideologias de gênero e gênesis nos discursos de Magno Malta

BRASIL. Senado. Pronunciamento de Magno Malta em 24/05/2011. Disponível em: https:// www25.senado.leg.br/web/atividade/pronunciamentos/-/p/texto/389338. Acesso em 02 dez. 2018.

BRASIL. Senado. Pronunciamento de Magno Malta em 20/11/2013. Disponível em: https:// www25.senado.leg.br/web/atividade/pronunciamentos/-/p/texto/404544. Acesso em 02 dez. 2018.

BRASIL. Senado. Pronunciamento de Magno Malta em 08/06/2015. Disponível em: https:// www25.senado.leg.br/web/atividade/pronunciamentos/-/p/texto/414271. Acesso em 02 dez. 2018.

BRASIL. Senado. Pronunciamento de Magno Malta em 18/10/2017. Disponível em: https:// www25.senado.leg.br/web/atividade/pronunciamentos/-/p/texto/437521. Acesso em 02 dez. 2018.

BRASIL. Senado. Pronunciamento de Magno Malta em 05/02/2018. Disponível em: https:// www25.senado.leg.br/web/atividade/pronunciamentos/-/p/texto/440973. Acesso em 02 dez. 2018.

BRASIL. Senado. E-Cidadania. Regular a interrupção voluntária da gravidez, dentro das 12 primeiras semanas de gestação, pelo Sistema Único de Saúde. Disponível em: https://www12. senado.leg.br/ecidadania/visualizacaoideia?id=29984. Acesso em 02 dez. 2018.

BRASIL. Senador Magno Malta. Senado Federal - Perfil Parlamentar. Disponível em: https:// www12.senado.leg.br/noticias/tablet/perfilparlamentar/631. Acesso em 02 dez. 2018.

BRASIL. Senador Magno Malta. Senado Federal - Missões no Exterior. Disponível em: https://www25.senado.leg.br/web/senadores/senador/-/perfil/631\#accordion-biografia. Acesso em 02 dez. 2018.

BRASIL. Senado Notícias. Debatedores acusam TSE, Ministério Público e PF de omissão em relação a fake news (13/12/2018). Acesso em: www12.senado.leg.br/noticias/ materias/2018/12/13/debatedores-acusam-tse-ministerio-publico-e-pf-de-omissao-em-relacaoa-fake-news. Acesso em: 14 dez. 2018.

BRASIL. Senado Notícias. Magno Malta pede arquivamento de sugestão legislativa que legaliza aborto (05/02/2018). Disponível em: https://www12.senado.leg.br/noticias/ materias/2018/02/05/magno-malta-pede-arquivamento-de-sugestao-legislativa-que-legalizaaborto. Acesso em 02 dez. 2018.

BRASIL, Senado Notícias. Magno Malta teme aceitação da pedofilia pela sociedade. 06/11/2013. Disponível em: https://www12.senado.leg.br/noticias/materias/2013/11/06/ magno-malta-teme-aceitacao-da-pedofilia-pela-sociedade. Acesso em 02 dez. 2018.

BRASIL. Senado Notícias. Magno Malta critica ideologia de gênero e ataques à família (05/02/2018). Disponível em: https://www12.senado.leg.br/noticias/materias/2018/02/05/ magno-malta-critica-ideologia-de-genero-e-ataques-a-familia. Acesso em 02 dez. 2018.

Conselho livra da cassação Suassuna, Serys e Malta (28/11/2006). Folha de S. Paulo. Disponível em: https://www1.folha.uol.com.br/folha/brasil/ult96u87159.shtml. Acesso em 02 dez. 2018.

CPI dos Sanguessugas denuncia 72 parlamentares; veja lista (10/08/2006). Folha de S. Paulo. 


\section{Eduardo Meinberg de Albuquerque Maranhão $F^{o}$.}

Disponível em: https://www1.folha.uol.com.br/folha/brasil/ult96u81238.shtml. Acesso em 02 dez. 2018.

EQUIPE CHRISTO NIHIL PRAEPONERE. O feminismo é tão inimigo das mulheres quanto o machismo. Compartilhando a graça. Disponível em: <http:// permanecerecompartilhar.blogspot.com.br/2014/01/o-feminismo-e-tao-inimigo-das-mulheres. html?utmsource $=$ feedburner\&utm_medium $=$ feed\&utm_mpaign $=$ Feed: + compartilhandoagrac a+(Compartilhando+a+Gra\%C3\%A7a)\#.VDUnqWddXfI>. Acesso em 02 dez. 2018.

Esclarecimento para as eleições 2010 (01/10/2010). Folha do Litoral. Disponível em: http:// www.folhalitoral.com.br/site/?p=materias_ver\&id=1077. Acesso em 02 dez. 2018.

KELlER, Antônio Carlos Rossi. A condenação da ideologia de gênero. Confraria dos penitentes de São João Batista. 26 mar. 2014. Disponível em: https://confrariadesaojoaobatista. blogspot.com/. Acesso em: 5 ago. 2014.

Magno Malta. Site pessoal. Disponível em: http://magnomalta.com/ Acesso em 02 dez. 2018.

Magno Malta. Perfil na Wikipedia. Disponível em: https://pt.wikipedia.org/wiki/Magno_ Malta\#cite_note-3. Acesso em 02 dez. 2018.

Magno Malta: "PLC 122 é como legalizar a pedofilia e o sadomasoquismo" (27/02/2011). Gospel Prime. Disponível em: https://noticias.gospelprime.com.br/magno-malta-plc-122-ecomo-legalizar-a-pedofilia-e-o-sadomasoquismo/. Acesso em 02 dez. 2018.

Oração de Magno Malta na Vitória de Jair Bolsonaro (28/10/2018). Canal de Youtube de Magno Malta: Disponível em: https://www.youtube.com/watch?v=ixUfHHJnMjo. Acesso em 02 dez. 2018.

Perfil de Magno Malta na Wikipédia é adulterado após excluir escândalos (01/09/2016). G1 Espírito Santo. Disponível em: http://g1.globo.com/espirito-santo/noticia/2016/09/perfil-demagno-malta-na-wikipedia-e-vandalizado-apos-excluir-escandalos.html. Acesso em 02 dez. 2018.

Presidente da Associação dos Pastores critica exploração da pedofilia como campanha política (13/09/2010). Gazeta Online. Disponível em: http://gazetaonline.globo.com/_ conteudo/2010/09/667366-presidente + da + associacao + dos + pastores + critica + exploracao + da+pedofilia+como+campanha+politica.html Acesso em 02 dez. 2018.

Senador Magno Malta. Canal do Youtube. Disponível em: https://www.youtube.com/user/ senadormagnomalta. Acesso em 02 dez. 2018.

VERITATIS. A ideologia de gênero: seus perigos e alcances. 09 de junho de 2008. Disponível em: www.veritatis.com.br/doutrina/documentos-da-igreja/ 6616-a-ideologia-do-genero-seusperigos-e-alcances. Acesso em 07 set. 2017.

Submetido em: 18-4-2019

Aceito em: 27-1-2022 